\title{
The fiftieth anniversary of hypoglycaemic sulphonamides. How did the mother compound work?
}

\author{
J.-C. Henquin \\ Unité de Diabétologie et Nutrition, University of Louvain School of Medicine, Brussels, Belgium; \\ and I. Physiologisches Institut, University of Saarland, FRG
}

Probably over 20 million patients world-wide suffering from Type 2 (non-insulin-dependent) diabetes mellitus are treated with hypoglycaemic sulphonylureas. In fact, all antidiabetic drugs currently used with the aim of stimulating insulin release belong to this family.

Soon after the discovery of insulin, Abel and Geiling [1] showed that the hormone contains large amounts of sulphur which is essential for its biological action. These observations prompted several studies on the possible effects of sulphur itself on glucose homeostasis. Oral and parenteral administration of colloidal sulphur caused a small decrease in blood glucose levels in normal rabbits and humans [2-4] and slightly lowered glycaemia and glucosuria in certain diabetic patients $[4,5]$. The mechanisms of action of sulphur have not been clearly identified.

The first report that a synthetic sulphur-containing compound may lower blood glucose probably dates from 1930 [6]. Ruiz and collaborators observed that oral or intravenous administration of 4- or 5-methyl, 2-thiolimidazole (Fig.1) to normal fasting rabbits was followed by a slight decrease of glycaemia, but the mechanism involved was not elucidated [6].

\section{From a clinical observation with compound 2254 RP ...}

The story of the hypoglycaemic sulphonamides started in France, 50 years ago. In the spring of 1942, Marcel Janbon from the Clinic of the Montpellier Medical School evaluated the efficacy of a sulphonamide, compound 2254 RP (p-aminobenzenesulphamido-isopropylthiodiazol) (Fig. 1) in the treatment of typhoid fever. This compound (also known as VK 57 or IPTD) had been synthesized one year earlier by Vonkennel and Kimmig [7], and found to have a slight bacteriostatic effect on the typhoid bacillus. After the unexplained death of some of their patients, Janbon and his collaborators realized that 2254 RP was causing hypoglycaemia [8, 9]. In June 1942, this "side-effect" of the drug was confirmed experimentally by Auguste Loubatières [10], who then undertook a careful study of the mechanisms underlying this hypoglycaemia [11-13].

He demonstrated that, whatever the route of administration, $2254 \mathrm{RP}$ decreased blood glucose levels in normal dogs. This hypoglycaemic effect was unaffected by vagotomy, persisted in partially pancreatectomized animals, but disappeared when the pancreatectomy was complete. The degree of hypoglycaemia was dependent on the sulphonamide concentration in plasma, but low doses were sufficient to cause a marked fall in blood glucose when they were injected directly into the pancreatic artery [11-13].

These observations led Loubatières to propose that the hypoglycaemic property of $2254 \mathrm{RP}$ was due to its ability to stimulate insulin release through a direct action on Beta cells. Further support for this interpretation was obtained in cross-circulation experiments. When the pancreaticoduodenal vein of a normal donor dog was anastomosed to the jugular vein of a receiver dog made diabetic by alloxan, injection of the drug to the donor was followed by a decrease in blood glucose levels in the receiver [12]. The hypoglycaemic effects of $2254 \mathrm{RP}$ and of a related com-
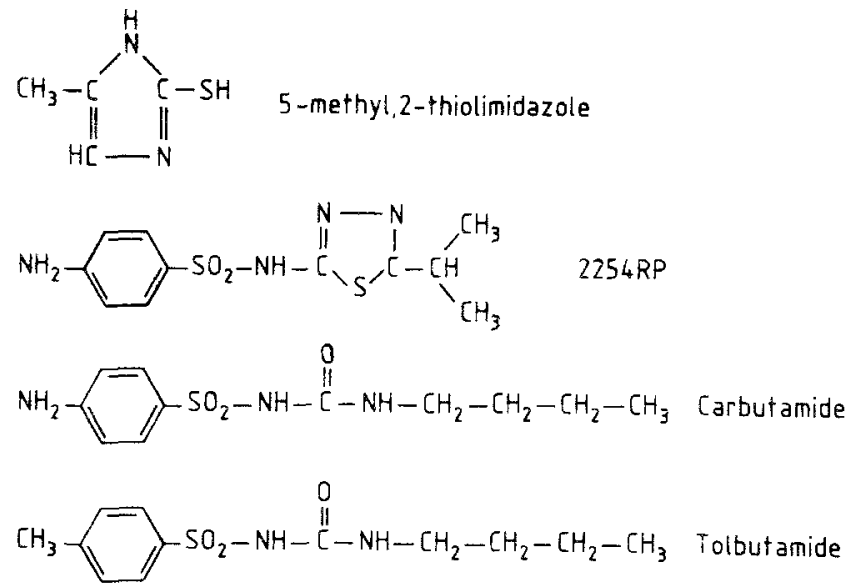

Fig. 1. Structural formulae of 4-methyl,2-thiolimidazole, compound 2254 RP, carbutamide and tolbutamide 


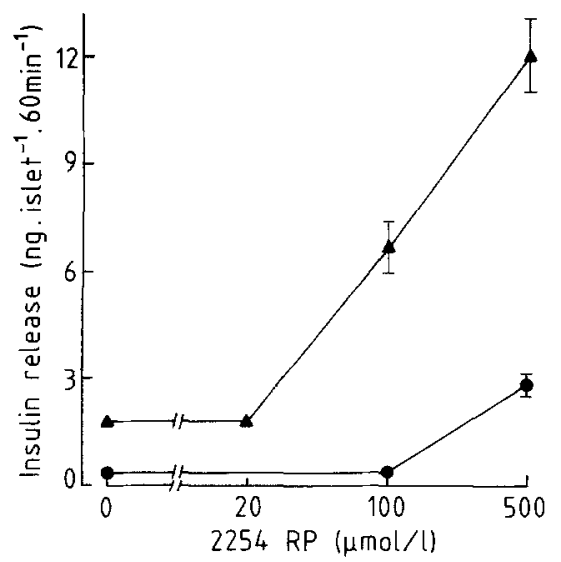

Fig. 2. Effects of various concentrations of $2254 \mathrm{RP}$ on insulin release by mouse islets incubated in a medium containing $3(\bullet)$ or 10 (A) $\mathrm{mmol} / /$ glucose. Values are means $\pm \mathrm{SEM}$ for 12 batches of islets

pound were rapidly confirmed by Chen et al. [14] and by La Barre and Reuse [15]. These authors further showed that the drug remained effective in alloxan-diabetic dogs provided the destruction of Beta cells was not complete.

In the mid-1950s, morphological studies of the pancreas of animals treated with $2254 \mathrm{RP}$ temporarily cast doubt on Loubatières' interpretation of the mode of action of the drug. These studies suggested that the hypoglycaemic property was due to a destruction of glucagon-secreting Alpha cells $[16,17]$. That $2254 \mathrm{RP}$ affected the morphological appearance of Alpha cells was confirmed $[18,19]$, but Gepts and collaborators [19] pointed out that the cells were degranulated, not severely damaged. They also noted that Beta cells were degranulated by the treatment [19].

Structure-activity studies were carried out very early in man by Janbon [20], in dogs by Bovet and Dubost [21], and in rabbits by Loubatières [22]. The results suggested that both the sulphonamide group and the nature of the side chain were important for the hypoglycaemic action.

Although Loubatières had already suggested in his thesis published in 1946 [12] that "such hypoglycaemic drugs could be useful in the treatment of certain forms of functional diabetes characterized by a sluggishness of the insulin-secretory mechanisms", only few clinical assays were performed up to 1955 [23-25]. These assays showed that $2254 \mathrm{RP}$ lowered glycaemia and glucosuria in patients whose diabetes did not require insulin treatment, but could never be substituted for insulin in patients with more severe diabetes.

\section{... to the sulphonylureas...}

In the spring of 1954, a similar story was taking place in Berlin. Franke and Fuchs [26] noted that a new sulphonamide, that was being tested in the treatment of various bacterial infections, caused hypoglycaemia in normal subjects. This compound, known as BZ 55 or carbutamide (Fig. 1), differed from 2254 RP by the substitution of the isopropylthiodiazol moiety with an n-butylurea group.
J.-C.Henquin: The fiftieth anniversary of hypoglycaemic sulphonamides

The hypoglycaemic effects first observed in normal human subjects were confirmed in animals [27] and the drug was rapidly tested in diabetic patients. Carbutamide was found to lower blood glucose levels and decrease glucosuria in adult diabetic subjects who did not require insulin treatment $[26,28]$. It has been claimed by Kleinsorge that the hypoglycaemic effects of carbutamide (also known as compound $\mathrm{Ca} 1022$ ) had already been studied in a large number of patients in 1952-1953. However, this information was not published in the scientific literature until 1956 [29].

Shortly after, tolbutamide (Fig. 1) was synthesized [30] and found to possess no bacteriostatic but clear hypoglycaemic properties. A number of experimental and clinical studies established its usefulness in the treatment of certain forms of diabetes [31]. Glibenclamide, the first of the more potent sulphonylureas of the "second generation" became available in 1966 [32].

At the end of 1956, despite the general agreement that sulphonylureas had no effect on blood glucose in the complete absence of insulin, it was not at all clear that their primary action is to stimulate insulin release $[33,34]$. The major steps leading to this demonstration were the following.

The first studies were directly inspired by those performed 10 years earlier by Loubatières with $2254 \mathrm{RP}$. Cross-circulation experiments between hepatectomized donor dogs and normal recipients showed that sulphonylurea injection to the donor caused hypoglycaemia in the recipient [35]. It was also observed that low doses of sulphonylurea, which were ineffective when injected in a peripheral vein, caused hypoglycaemia when injected in the pancreatic artery [36].

The initial attempts to demonstrate an increase in plasma insulin levels after sulphonylurea administration were not conclusive largely because of the limitations of the insulin bioassays which were then available. These assays, however, detected an increase in plasma insulin when blood was sampled from the pancreatic vein of rats [37], and subsequently in peripheral blood from human subjects [38-40] receiving sulphonylureas. The advent of radioimmunoassays then made it clear that these drugs acutely increase the plasma insulin concentration [41].

In vivo treatment with sulphonylureas was soon found to cause degranulation of Beta cells $[42,43]$ and to lower the insulin content of the pancreas $[44,45]$. It was, however, not immediately clear whether this reflected decreased production or increased secretion of insulin. Convincing support for the latter interpretation was provided by ultrastructural studies showing margination of insulin granules and abundant exocytotic figures in Beta cells of animals treated with tolbutamide [46].

In vitro techniques to study insulin release were developed in the 1960s. Using a paper chromatography method to measure insulin, it was first shown that carbutamide increases insulin release from the isolated and perfused dog pancreas [47]. This was then confirmed with an insulin bioassay [48], that was also used to demonstrate that tolbutamide stimulates insulin release from fragments of rat pancreas [49]. Insulin radioimmunoassays eventually made it possible to establish the stimulatory ef- 

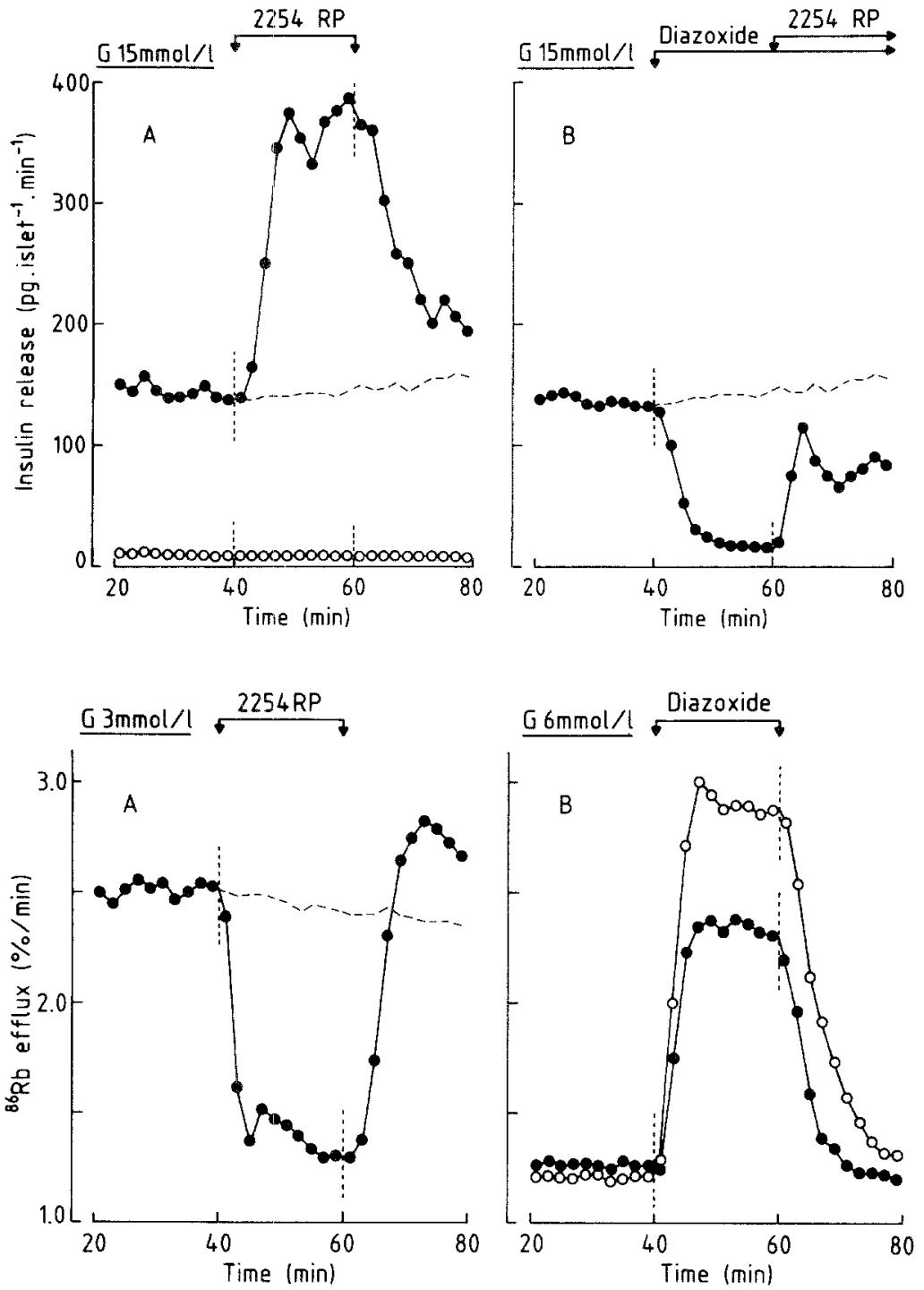

Fig. 3 A, B. Effects of 2254 RP on insulin release by mouse islets perifused with a medium containing $15 \mathrm{mmol} / \mathrm{l}$ glucose $(\mathrm{G})$. In $\mathbf{A}$ one series of experiments (O) was made in the absence of $\mathrm{Ca}^{2+} .2254 \mathrm{RP}$ $(100 \mu \mathrm{mol} / \mathrm{l})$ and diazoxide $(50 \mu \mathrm{mol} / \mathrm{l})$ were added for the indicated periods. Control release in the presence of glucose alone is shown by the broken lines. Values are means of two experiments

Fig. 4A,B. Effects of $2254 \mathrm{RP}$ on the efflux of ${ }^{86} \mathrm{Rb}$ (used as a tracer for potassium) from perifused mouse islets $\mathbf{A}$. The concentration of glucose $(\mathrm{G})$ was $3 \mathrm{mmol} / \mathrm{l}$ and $2254 \mathrm{RP}(500 \mu \mathrm{mol} / \mathrm{l})$ was added between 40 and $60 \mathrm{~min}$. Control experiments without $2254 \mathrm{RP}$ are shown by the broken line $\mathbf{B}$. The concentration of glucose $(\mathrm{G})$ was $6 \mathrm{mmol} / \mathrm{l}$ and diazoxide $(100 \mu \mathrm{mol} / \mathrm{l})$ was added between 40 and $60 \mathrm{~min}$. In one series ( ) $2254 \mathrm{RP}$ $(100 \mu \mathrm{mol} / \mathrm{l})$ was present throughout. Values are means of two experiments. The methods used in these experiments have been described previously [60] fects of sulphonylureas on Beta cells in pieces of rabbit pancreas [50], in the perfused rat pancreas [51] and in isolated rat islets [52].

Since then numerous studies have been devoted to the elucidation of the cellular mechanisms by which sulphonylureas influence Beta cell function. These will not be reviewed again here because several recent articles have dealt with this question [53-57]. I found it more interesting and amusing to determine if and how compound $2254 \mathrm{RP}$, the molecule with which the whole story started, affects Beta cells.

\section{... and back}

The remainder of a batch (No 4443) of 2254 RP used by Loubatières himself was found, well-preserved by the dry climate of Montpellier, and was generously made available to me by Prof. M. M.Loubatières-Mariani. The effects of the drug were investigated in vitro with islets isolated from normal mice.

Figure 2 shows that basal insulin release by islets incubated in a medium containing $3 \mathrm{mmol} / \mathrm{l}$ glucose was unaf- fected by $100 \mu \mathrm{mol} / \mathrm{l}$ and increased about seven-fold by $500 \mu \mathrm{mol} / 12254 \mathrm{RP}$. It also shows that insulin release induced by $10 \mathrm{mmol} / 1$ glucose was not modified by $20 \mu \mathrm{mol} / 1$ $2254 \mathrm{RP}$, but was potentiated approximately four- and seven-fold by 100 and $500 \mu \mathrm{mol} / 12254 \mathrm{RP}$, respectively. In dogs acutely treated with 2254 RP Loubatières usually measured a total sulphonamidaemia between 30 and $150 \mathrm{mg} / 1$ [12], which corresponds to $100-500 \mu \mathrm{mol} / 1$ $2254 \mathrm{RP}$. Although the assay also measured metabolites of the drug, the concentrations were well within the range of those that are effective on Beta cells in vitro. These observations thus establish that Loubatières was correct in his assumption that $2254 \mathrm{RP}$ directly stimulates pancreatic Beta cells to release insulin.

Experiments with perifused islets showed that the increase in insulin release brought about by $2254 \mathrm{RP}$ is rapid and reversible, and that omission of calcium from the medium prevented both glucose and 2254 RP from stimulating insulin release (Fig. 3).

In the presence of a low concentration of glucose $(3 \mathrm{mmol} / \mathrm{l})$, the potassium permeability of the Beta-cell membrane is high because many ATP-sensitive $\mathrm{K}^{+}$chan- 


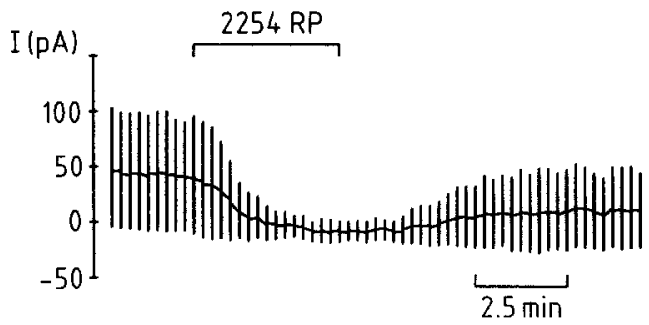

Fig.5. Effects of 2254 RP on ATP-sensitive $\mathrm{K}^{+}$currents in a mouse Beta cell. Currents were recorded with the whole cell mode of the patch clamp technique as previously described [63]. Currents were evoked by pulses to -60 and $-80 \mathrm{mV}$ from a holding potential of $70 \mathrm{mV}$. The size of the upward and downward deflections indicates the size of the current (I). The recording starts 2 min after establishment of the whole cell configuration. $2254 \mathrm{RP}(500 \mu \mathrm{mol} / \mathrm{l})$ was added for the indicated period. The recording is representative of results obtained in three different cells
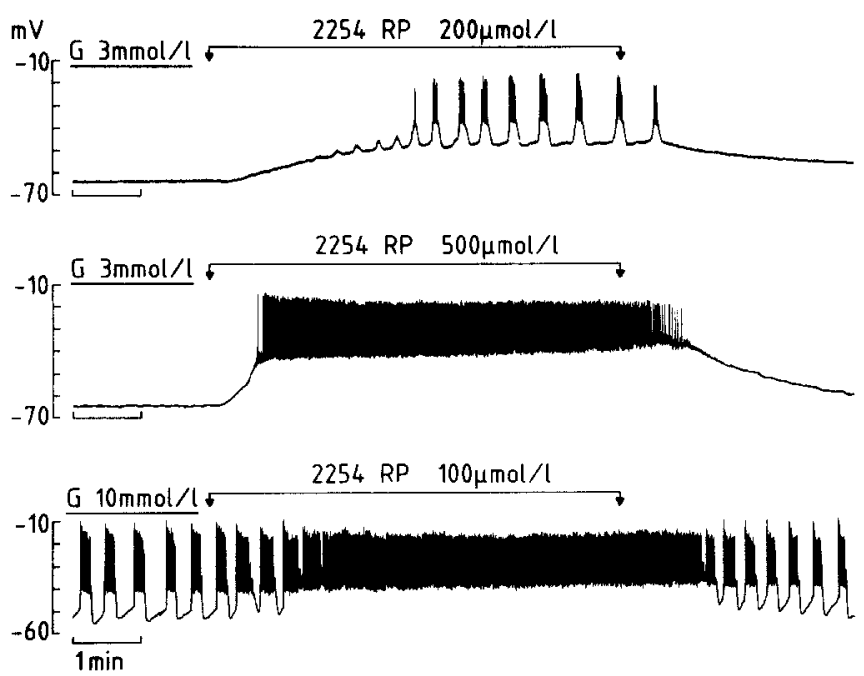

Fig. 6. Effects of 2254 RP on the membrane potential of mouse Beta cells perifused with a medium containing 3 or $10 \mathrm{mmol} / 1$ glucose $(G)$. $2254 \mathrm{RP}$ was added at the concentrations and for the periods indicated on top of the panels. The recordings were obtained with an intracellular microelectrode technique [64]. Similar results have been obtained in two experiments

nels are open $[58,59]$. This explains why the efflux rate of ${ }^{86} \mathrm{Rb}$ (a tracer of potassium [60]) from islet cells is high (Fig.4). Addition of $2254 \mathrm{RP}$ rapidly and reversibly decreased this rate of efflux. In the presence of $6 \mathrm{mmol} / 1 \mathrm{glu}-$ cose, the rate of ${ }^{86} \mathrm{Rb}$ efflux is low because most ATP-sensitive $\mathrm{K}^{+}$channels are closed [58, 59]. Diazoxide, a selective opener of these channels [61], caused a marked acceleration of ${ }^{86} \mathrm{Rb}$ efflux which could be partially antagonized by an equimolar concentration of $2254 \mathrm{RP}$ (Fig. 4). The opening of ATP-sensitive $\mathrm{K}^{+}$channels by diazoxide repolarizes the Beta-cell membrane [62] and inhibits glucose-induced insulin release. This inhibition was partially reversed by 2254 RP (Fig. 3). All these observations indirectly indicate that $2254 \mathrm{RP}$ closes ATP-sensitive $\mathrm{K}^{+}$channels.

This closure was directly demonstrated by the patchclamp technique. When a Beta cell is dialysed with a pipette solution containing a low concentration of ATP and its membrane potential held at $-70 \mathrm{mV}$ (resting level),
J.-C. Henquin: The fiftieth anniversary of hypoglycaemic sulphonamides

ATP-sensitive $\mathrm{K}^{+}$currents can be selectively triggered by pulses to -60 and $-80 \mathrm{mV}[61,63]$. As shown in Figure 5, 2254 RP rapidly and reversibly inhibited these currents.

The decrease in potassium conductance resulting from the closure of ATP-sensitive $\mathrm{K}^{*}$ channels may be expected to cause depolarization of the Beta-cell membrane. When islets were perifused with a medium containing only $3 \mathrm{mmol} / \mathrm{l}$ glucose, the resting potential of Beta cells was about $-65 \mathrm{mV}$. Addition of $2254 \mathrm{RP}$ was followed by a depolarization and appearance of electrical activity the intensity of which increased with the concentration of the drug (Fig. 6). In the presence of $10 \mathrm{mmol} / \mathrm{l}$ glucose, Beta cells exhibited their typical electrical activity consisting of slow waves of the membrane potential with bursts of spikes superimposed on the plateau [64]. After addition of 2254 RP the duration of slow waves increased before the depolarization at the plateau potential became sustained and the spike activity became continuous (Fig. 6).

Since this electrical activity reflects $\mathrm{Ca}^{2+}$ influx through voltage-dependent $\mathrm{Ca}^{2+}$ channels [65], the effects of $2254 \mathrm{RP}$ on the concentration of cytoplasmic $\mathrm{Ca}^{2+}$ in Beta cells were measured. In non-stimulated Beta cells ( $3 \mathrm{mmol} / \mathrm{l}$ glucose), $\mathrm{Ca}^{2+}{ }_{1}$ was low and stable; it was markedly increased by $2254 \mathrm{RP}$ (Fig. 7). In the presence of $15 \mathrm{mmol} / \mathrm{l}$ glucose, $\mathrm{Ca}^{2+}{ }_{\mathrm{i}}$ was higher and displayed regular oscillations [66]. Addition of $2254 \mathrm{RP}$ was followed by a sustained increase in $\mathrm{Ca}^{2+}{ }_{i}$ (Fig.7).

\section{Conclusions}

The mode of action of $2245 \mathrm{RP}$ in Beta cells can be schematically represented as follows (Fig. 8). By closing ATPsensitive $\mathrm{K}^{+}$channels, 2254 RP causes a decrease in potassium conductance of the Beta-cell membrane that leads to depolarization with activation of voltage-dependent $\mathrm{Ca}^{2+}$ channels. The ensuing influx of $\mathrm{Ca}^{2+}$ raises the concentration of free cytoplasmic $\mathrm{Ca}^{2+}$, which activates an effector system eventually responsible for exocytosis of insulin granules. This sequence of events is similar to that triggered by sulphonylureas of the first or second generation.

Given their central role in the control of Beta-cell membrane potential, ATP-sensitive $\mathrm{K}^{+}$channels are an
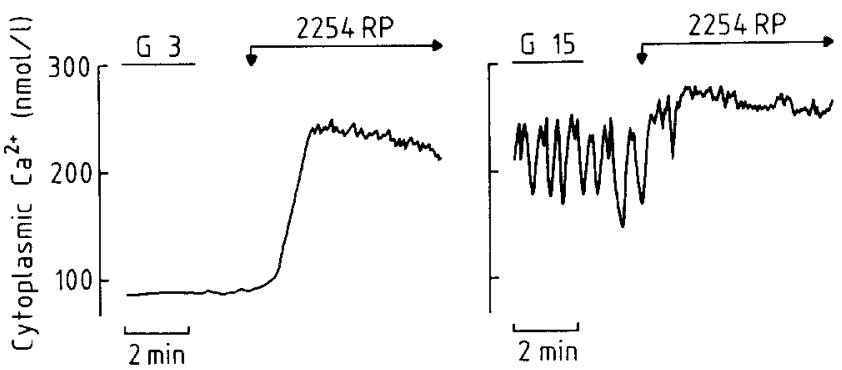

Fig. 7. Effects of $2254 \mathrm{RP}$ on the concentration of cytoplasmic $\mathrm{Ca}^{2+}$ in mouse Beta cells. The concentration of $\mathrm{Ca}^{2+}$ was measured in islets loaded with the $\mathrm{Ca}^{2+}$ fluorochrome fura-2 [66] and perifused with a medium containing 3 or $15 \mathrm{mmol} / \mathrm{l}$ glucose $(\mathrm{G}) .2254 \mathrm{RP}$ was added at the concentrations of $500 \mu \mathrm{mol} / 1$ (left) and $250 \mu \mathrm{mol} / 1$ (right) for the periods indicated at the top of the panels. The traces are representative of results obtained with three islets 


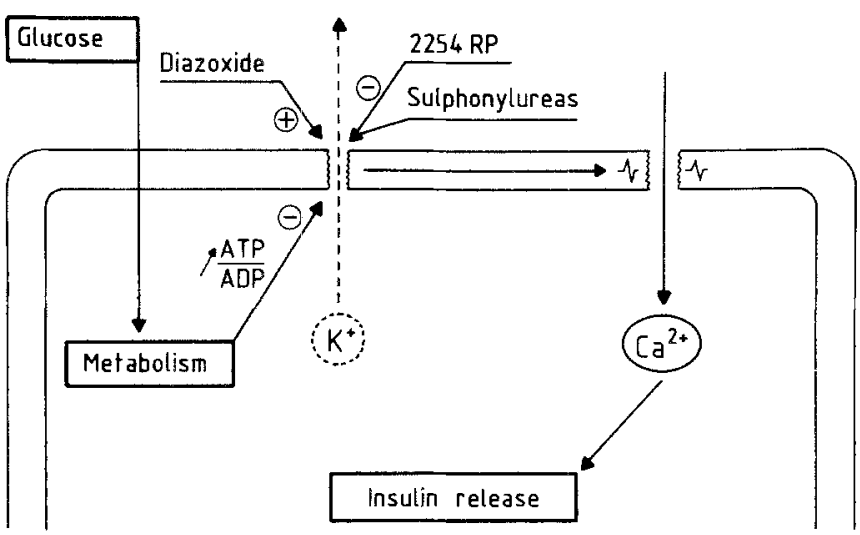

Fig.8. Schematic representation of the major mechanisms by which glucose, compound $2254 \mathrm{RP}$ and sulphonylureas stimulate insulin release

exquisitely sensitive target for pharmacological agents purported to affect Beta-cell function. All hypoglycaemic drugs that we currently use to correct the insufficient release of insulin in Type 2 diabetic patients act on this target. New substances, be they sulphonamides or not, able to cause a rapid and short-term inhibition of ATP-sensitive $\mathrm{K}^{+}$channels would certainly enrich our therapeutic arsenal. However, with the improvement of our understanding of Beta-cell physiology and pathophysiology has come the time to look for drugs acting at other sites [53]. It would be unwise to deliberately restrict our therapeutic means to compounds aiming at the same single target for another 50 years.

Acknowledgements. I am most grateful to Prof. M. M.LoubatièresMariani for providing me with $2254 \mathrm{RP}$ and with several documents. The experiments with $2254 \mathrm{RP}$ were performed by P.Gilon, J.C. Jonas, M.Nenquin, T.Plant and W.Schmeer whom I thank for their collaboration. I am Directeur de Recherches of the Fonds National de la Recherche Scientifique, Brussels.

\section{References}

1. Abel JJ, Geiling EMK (1925) Researches on insulin. I. Is insulin an unstable sulphur compound? J Pharmacol Exp Ther 25: 423448

2. Gordonoff T (1926) Ueber eine neue Indikation der Schwefel therapie. Schweiz Med Wochenschr 7: 1125-1126

3. Campanacci D, Balducci R (1926) Hypoglykämische Wirkung des Schwefels. Klin Wochenschr 5:2166-2167

4. Pennetti G (1928) L'azione ipoglicemizzante dello solfo colloi dale. Arch Int Pharmacodyn Ther 34: 214-223

5. Földes E (1927) Wirkung peroraler Schwefelzufuhr auf die diabetische Stoffwechselstörung. Z Gesamte Exp Med 55: 615626

6. Ruiz CL, Silva LL, Libenson L (1930) Contribucion al estudio sobre la composicion quimica de la insulina: estudio de algunos cuerpos sinteticos sulfurados con accion hipoglucemiante. Rev Soc Argentina Biol 6: 134-141

7. Vonkennel J, Kimmig J (1941) Versuche und Untersuchungen mit neuen Sulfonamiden. Klin Wochenschr 20:2-8

8. Janbon M, Chaptal J, Vedel A, Schaap J (1942) Accidents hypoglycémiques graves par un sulfamidothiodiazol (le VK 57 ou 2254 RP). Montpellier Med 21-22: 441-444
9. Janbon M, Lazerges P, Metropolitanski JH (1942) Etude du métabolisme du sulfaisopropyl-thiodiazol (VK 57 ou 2254 RP) chez le sujet sain et en cours de traitement. Comportement de la glycémie. Montpellier Med 21-22: 489-490

10. Loubatières A, Goldstein L, Metropolitanski J, Schaap J (1942) Etude expérimentale chez le chien des accidents nerveux irréversibles consécutifs à l'hypoglycémie prolongée provoqué par le sulfa-isopropylthiodiazol. 43eme Congrès des Médecins aliénistes et neurologistes de France et des pays de langue française, Montpellier. Massin, Paris, p 415

11. Loubatières A (1944) Analyse du mécanisme de l'action hypoglycémiante du p-aminobenzène-sulfamido-isopropylthiodiazol (2254 RP). CR Soc Biol (Paris) 138: 766-767

12. Loubatières A (1946) Physiologie et pharmacodynamie de certains dérivés sulfamidés hypoglycémiants. Contribution à l'étude des substances synthétiques à tropisme endocrinien. Thèse Doctorat ès-Sciences Naturelles, Université de Montpellier. Montpellier, pp 1-93

13. Loubatières A (1946) Etude physiologique et pharmacodynamique de certains dérivés sulfamidés hypoglycémiants. Arch Int Physiol 54: 174-177

14. Chen KK, Anderson RC, Maze N (1946) Hypoglycemic action of sulfanilamidocyclopropylthiazol in rabbits and its reversal by alloxan. Proc Soc Exp Biol 63: 483-486

15. La Barre J, Reuse J (1947) A propos de l'action hypoglycémiante de certains dérivés sulfamidés. Arch Neerl Physiol 28: 475-480

16. von Holt C, von Holt L, Kröner B, Kühnau J (1954) Chemische Ausschaltung der A-Zellen der Langerhansschen Inseln. Naturwissenschaften 41:166-167

17. von Holt C, von Holt L, Kröner B, Kühnau J (1955) Chemische Ausschaltung von A-Zellen der Langerhansschen Inseln. Arch Exp Pathol Pharmacol 224: 66-77

18. Loubatières A, Bouyard P, Fruteau de Laclos C (1955) Actions du para-aminobenzène-sulfamido-isopropylthiodiazol sur la glycémie, la structure des îlots de Langerhans et le métabolisme de l'animal normal ou diabétique. C R Soc Biol 149: 1642-1646

19. Gepts W, Christophe J, Bellens R (1955) Etude expérimentale d'un sulfamidé hypoglycémiant. Modifications morphologiques, et en particulier pancréatiques, provoquées chez le rat normal et le rat diabétique par le RP 2254. Ann Endocrinol 16: 946-955

20. Janbon M, Lazerges P, Metropolitanski JH, Schaap JD (1943) Action hypoglycémiante de certains composés sulfamidés. Rôle du radical propylthiodiazol. Montpellier Med 23-24: 132-136

21. Bovet D, Dubost P (1944) Activité hypoglycémiante des aminobenzène-sulfamido-alkylthiodiazols. Rapports entre la constitution et l'activité pharmacodynamique. CR Soc Biol (Paris) 138: 764-765

22. Loubatières A (1944) Relations entre la structure moléculaire et l'activité hypoglycémiante des aminobenzène-sulfamido-alkylthiodiazols. CR Soc Biol (Paris) 138: 830-831

23. Loubatières A (1955) Action curative du p-aminobenzène-sulfamido-isopropyl-thiodiazol dans le diabète sucré humain. CR Acad Sci (Paris) 241: 1422-1423

24. Loubatières A, Fruteau de Laclos C, Bouyard P (1956) Le p-aminobenzène-sulfamido-isopropylthiodiazol dans le traitement du diabète sucré. Sem Hôp Paris 32: 2358-2368

25. Azérad E (1956) Essai de traitement du diabète sucré de l'adulte par des hypoglycémiants de synthèse de la série des sulfamidothiodiazols (2254 et $2261 \mathrm{RP}$ ). Bull Mém Soc Med Hôp Paris 72: 424-435

26. Franke H, Fuchs J (1955) Ein neues antidiabetisches Prinzip. Dtsch Med Wochenschr 80: 1449-1452

27. Achelis JD, Hardebeck K (1955) Über eine neue blutzuckersenkende Substanz. Dtsch Med Wochenschr 80: 1452-1455

28. Bertram F, Bendfeldt E, Otto $H$ (1955) Über ein wirksames perorales Antidiabeticum (BZ 55). Dtsch Med Wochenschr 80: $1455-1460$

29. Kleinsorge H (1956) Bemerkung zu den Arbeiten über $\mathrm{N}_{1}$-sulfamilyl- $\mathrm{N}_{2}$-n-butylcarbamid als perorales Antidiabetikum. Dtsch Med Wochenschr 81: 750-751 
30. Ehrhart G (1956) Über neue peroral wirksame blutzuckersenkende Substanzen. Naturwissenschaften 43: 93

31. Bänder A, Creutzfeldt W, Dorfmüller Th et al. (1956) Über die orale Behandlung des Diabetes mellitus mit N-(4-Methyl-benzolsulfonyl)-N'-butylharnstoff (D 860). Dtsch Med Wochenschr 81: 823-846

32. Aumüller W, Bänder A, Heerdt R et al. (1966) Ein neues, hoch wirksames Antidiabeticum. Arzn Forsch 16: 1640-1641

33. Levin R, Duncan GG (1956) Symposium on clinical and experimental effects of sulfonylureas in diabetes mellitus. Editorial statement. Metabolism 5: 721-726

34. Ricketts HT, Lukens FDW, Krahl ME (1957) Present state of knowledge concerning effects of the sulfonylurea compounds in diabetes mellitus. Diabetes 6: 91-92

35. Pozza G, Galansino G, Foa PP (1956) Insulin secretion following carbutamide injections in normal dogs. Proc Soc Exp Biol Med 93: 539-542

36. Colwell AR Jr, Colwell JA, Colwell AR Sr (1956) Intrapancre atic perfusion of the antidiabetic sulfonylureas. Metabolism 5: 749-756

37. von Holt C, von Holt L, Kracht J, Kröner B, Kühnau J (1957) Carbutamide and plasma insulin activity. Science 125: 735-736

38. Aiman R, Kulkarni RD (1957) The effect of human plasma on the glucose uptake of the rat diaphragm before and after administration of carbutamide. Br J Pharmacol 12: 475-478

39. Pfeiffer EF, Pfeiffer M, Ditschuneit H, Ahn CS (1959) Clinical and experimental studies of insulin secretion following tolbutamide and metahexamide administration. Ann NY Acad Sci 82: 479-495

40. Vallance-Owen J, Joplin GF, Fraser R (1959) Tolbutamide control of diabetes mellitus. Clinical responsiveness and insulin reserve. Lancet II: 584-586

41. Yalow RS, Black H, Villazon M, Berson SA (1960) Comparison of plasma insulin levels following administration of tolbutamide and glucose. Diabetes 9:356-362

42. Creutzfeldt W, Finter H (1956) Blutzucker und histologische Veränderungen nach D 860 bei normalen Kaninchen. Dtsch Med Wochenschr 81: 892-896

43. Gepts W, Christophe J, Bellens R (1956) Etude expérimentale de l'action du BZ 55 sur le rat normal ou alloxanisé. Modifications morphologiques et en particulier pancréatiques. Ann Endocrinol 17: 278-290

44. Root MA (1957) Effects of carbutamide on the insulin content of the dog pancreas. Diabetes 6:12-16

45. Pfeiffer EF, Steigerwald H, Sandritter W et al. (1957) Vergleichende Untersuchungen von Morphologie und Hormongehalt des Kälberpankreas nach Sulfonylharnstoffen (D 860). Disch Med Wochenschr 82: 1568-1574

46. Williamson JR, Lacy PE, Grisham JW (1961) Ultrastructural changes in islets of the rat produced by tolbutamide. Diabetes 10 : 460-469

47. Stuhlfauth K, Mehnert H, Schäfer G, Kaliampetsos G (1960) Untersuchungen zum Wirkungsmechanismus der Sulfonylharnstoffe. Klin Wochenschr 38: 825-826

48. Mehnert H, Schäfer G, Kaliampetsos G, Stuhlfauth K, Engelhardt W (1962) Die Insulinsekretion des Pankreas bei extracorporaler Perfusion. Durchströmungen der Bauchspeicheldrüse mit Periston, Glucose, Carbutamid und Biguaniden. Klin Wochenschr 40: 1146-1151

49. Bouman PR, Gaarenstroom JH (1961) Stimulation by carbutamide and tolbutamide of insulin release from rat pancreas in vitro. Metabolism 10: 1095-1099
50. Coore HG, Randle PJ (1964) Regulation of insulin secretion studied with pieces of rabbit pancreas incubated in vitro. Biochem $\mathrm{J}$ 93: $66-78$

51. Sussman KE, Vaughan GD, Timmer RF (1966) An in vitro method for studying insulin secretion in the perfused isolated rat pancreas. Metabolism 15: 466-476

52. Malaisse WJ, Malaisse-Lagae F, Mayhew DA, Wright PH (1967) Effects of sulfonylureas upon insulin secretion by the rat's pancreas. In: Butterfield WJH, von Westering W (eds) Tolbutamide after ten years. Excerpta Medica, Amsterdam, pp 49-60

53. Henquin JC (1990) Established, unsuspected and novel pharmacological insulin secretagogues. In: Bailey CJ, Flatt PR (eds) New antidiabetic drugs. Smith-Gordon, London, pp 93-106

54. Siconolfi-Baez L, Banerji MA, Lebovitz HE (1990) Characterization and significance of sulfonylurea receptors. Diabetes Care 13 [Suppl 3]:2-8

55. Ashford MLJ (1990) Potassium channels and modulation of insulin secretion. In: Cook NS (ed) Potassium channels: structure, classification, function and therapeutic potential. Ellis Horwood, Chichester, pp 300-325

56. Malaisse WJ, Lebrun P (1990) Mechanisms of sulfonylurea-induced insulin release. Diabetes Care 13 [Suppl 3]: 9-17

57. Boyd AE, Aguilar-Bryan L, Bryan J et al. (1991) Sulfonylurea signal transduction. Recent Prog Horm Res 47: 299-317

58. Rorsman P, Trube G (1985) Glucose-dependent $\mathrm{K}^{+}$channels in pancreatic beta cells are regulated by ATP. Pflügers Arch 405: 305-309

59. Misler S, Falke LC, Gillis K, McDaniel ML (1986) A metaboliteregulated potassium channel in rat pancreatic beta cells. Proc Natl Acad Sci USA 83: 7119-7123

60. Henquin JC (1979) Opposite effects of intracellular $\mathrm{Ca}^{2+}$ and glucose on $\mathrm{K}^{+}$permeability of pancreatic islet cells. Nature 280 : $66-68$

61. Trube G, Rorsman P, Ohno-Shosaku T (1986) Opposite effects of tolbutamide and diazoxide on the ATP-dependent $\mathrm{K}^{+}$channel in mouse pancreatic beta cells. Pflügers Arch 407: 493-499

62. Henquin JC, Meissner HP (1982) Opposite effects of tolbutamide and diazoxide on ${ }^{86} \mathrm{Rb}$ fluxes and membrane potential in pancreatic beta cells. Biochem Pharmacol 31:1407-1415

63. Plant TD, Jonas JC, Henquin JC (1991) Clonidine inhibits ATPsensitive $\mathrm{K}^{*}$ channels in mouse pancreatic beta cells. Br J Pharmacol 104: 385-390

64. Meissner HP, Schmelz H (1974) Membrane potential of beta cells in pancreatic islets. Pflügers Arch 351: 195-206

65. Henquin JC, Meissner HP (1984) Significance of ionic fluxes and changes in membrane potential for stimulus-secretion coupling in pancreatic B-cell. Experientia 40: 1043-1052

66. Zhang A, Gao ZY, Gilon P, Nenquin M, Drews G, Henquin JC (1991) Vanadate stimulation of insulin release in normal mouse islets. J Biol Chem 266: 21 649-21656

Dr. J.C.Henquin

Unité de Diabétologie et Nutrition

UCL 54.74

Avenue Hippocrate 54

B-1200 Brussels

Belgium 